\title{
FAKTOR- FAKTOR YANG MEMPENGARUHI KEPUTUSAN MAHASISWA UNTUK MENGONTRAK TEMPAT TINGGAL (STUDI KASUS MAHASISWA UTS NUSANTARA 2016)
}

\author{
Factors affecting student decision to contract a living place \\ (case study student uts nusantara 2016) \\ ${ }^{1}$ Muhammad Fady Ayyasy, ${ }^{2}$ Putri Reno Kemalasari, ${ }^{3}$ Fendy Maradita \\ Manajemen, Fakultas Ekonomi dan Bisnis, \\ Universitas Teknologi Sumbawa \\ JI. Raya Olat Maras, Batu Alang, Moyo Hulu, Kabupaten \\ Sumbawa \\ Email: muhammadfadyayyasy@gmail.com
}

\begin{abstract}
Abstrak
Ayyasy, Muhammad Fady. (2020). "Faktor- Faktor Yang Mempengaruhi Keputusan Mahasiswa Untuk Mengontrak Tempat Tinggal" (Studi Kasus Mahasiswa Uts Nusantara 2016). Skripsi, Program Studi Manajemen, Fakultas Ekonomi dan Bisnis, Universitas Tekonologi Sumbawa. Pembimbing (I) Putri Reno Kemalasari, M.A. (II) Fendi Maradita, M.M. Penelitian ini bertujuan untuk mengetahui faktor faktor yang mempengaruhi keputusan mahasiswa mengontrak tempat tinggal di wilayah perkotaan Sumbawa Besar. Landasan teori penelitian yang di gunakan yaitu bauran pemasaran yang biasa di sebut 7P dan faktor - faktor pengambilan keputusan (Budaya, Sosial, Psikologis). Populasi adalah seluruh mahasiswa aktif Universitas Teknologi Sumbawa angkatan 2016 dengan sampel sebanyak 6 orang dari setiap perwakilan fakultas. Penelitian ini dilakukan dengan wawancara terbuka dengan pertanyaan yang akan terus mendalam untuk mendapatkan jawaban yang baik menurut peneliti. Hasil dari penelitian ini adalah mahasiswa nusantara Universitas Teknologi Sumbawa lebih memilih tempat tinggal di wilayah perkotaan karena beberapa hal yang tidak ada di lingkungan kampus, seperti akses keseharian, hiburan, dan juga tempat tinggal yang masuk dalam ketegori modern menurut setiap informan.
\end{abstract}

Kata Kunci: Faktor, Keputusan, Mahasiswa

\begin{abstract}
Fady Ayyasy, Muhammad, 2019. Factors influencing the student decision to contract the residence. Thesis, management study Program, economics and business faculty, Sumbawa University of Technology, Mentor: (I) Putri Reno Kemala Sari, M.A. (II) Fendy Maradita, M.M.This research aims to determine the factors that influence the decision of the student to contract residence in the urban area of Sumbawa Besar. The foundation of research theory used is the usual marketing mix called 7P and the factors of decision-making (cultural, social, psychological). The population is an active student of the Sumbawa University Technology Force 2016 with a sample of 6 people from every faculty representative. The research was done with an open interview with a question that would hold in depth to get a good answer according to the researcher. The result of this research is the student of Nusantara Technology University of Sumbawa prefer the residence in the urban areas because of some things that do not exist in the campus environment, such as access to daily life, entertainment, and also the residence that is in In the modern category according to each informant.

Keywords: Factors, Decisions, Students
\end{abstract}




\section{PENDAHULUAN}

Pertumbuhan ekonomi Indonesia yang terus meningkat, serta arus modernisasi yang terus terjadi seiring perubahan zaman membuat terjadinya banyak perubahan terhadap suatu kehidupan disuatu daerah. Sudah menjadi hal wajar bahwa jumlah penduduk yang besar memberikan potensi konsumsi masyarakat dan faktor produksi tenaga kerja menjadi sumber pertumbuhan ekonomi. Menurut Sukirno (2010), pertumbuhan ekonomi adalah perkembangan kegiatan dalam perekonomian yang menyebabkan barang dan jasa yang di produksikan dalam masyarakat bertambah. Pertumbuhan ekonomi menunjukkan peningkatan dalam produksi barang maupun jasa dalam suatu qperekonomian, sehingga pertumbuhan ekonomi ini merupakan salah satu indikator penting di dalam melakukan suatu analisis pembangunan ekonomi (Nuraini, 2017). Pertumbuhan ekonomi secara agregat dapat dilihat dari PDB suatu negara. Tingginya nilai PDB di asumsikan bahwa kondisi perekonomian suatu negara tersebut juga baik. Setiap negara pada umumnya menginginkan pertumbuhan ekonomi yang pesat agar dapat meningkatkan taraf hidup dan kesejahteraan masyarakat. Salah satunya kota di Indonesia yang terus mengalami modernisasi terletak di Provinsi Nusa Tenggara Barat yaitu kota Sumbawa Besar. Sumbawa Besar merupakan kota yang menjadi pusat ekonomi bagi masyarakat yang berada di Kab. Sumbawa.

Perkembangan modernisasi (ekonomi) Kabupaten Sumbawa yang terjadi pada 5 tahun kebelakang dari tahun 2014-2018, bukan hanya terlihat pada kemajuan teknologi tetapi juga perubahan pembangunan dapat terlihat dari tahun ke tahun pada pola kehidupan masyarakat yang berubah ke arah modern.

Sumber: Badan Pusat Statistik

Pertumbuhan ekonomi berpengaruh terhadap perubahan pola kebutuhan pokok. Menurut Suryana (2008), kebutuhan pokok yang mendasar bagi setiap manusia terdiri dari kebutuhan sandang (pakaian), pangan (makanan) dan papan (tempat tinggal). Pada zaman yang modern ini kebutuhan manusia semakin beragam. Hal tersebut tercermin pada tingkat kebutuhan masyarakat yang semakin beragam dan semakin meningkat, sehingga mengakibatkan masyarakat kesulitan dalam hal menentukan mana kebutuhan primer dan mana kebutuhan sekunder. Namun, dari sekian banyak kebutuhan manusia, kebutuhan pangan, sandang, dan papan masih menjadi kebutuhan pokok yang mesti selalu menempati urutan atas dalam hal permintaan kebutuhan masyarakat. Ketika kebutuhan tersebut merupakan kebutuhan prioritas yang harus diutamakan. Semakin berkembangnya teknologi di berbagai bidang menjadikan banyak kebutuhan sekunder dan tersier yang beralih status menjadi kebutuhan primer.

Tempat tinggal sangatlah penting bagi semua orang, menjadi tempat dimana kita bisa beristirahat dan melakukan kegiatan yang kita inginkan. Menurut Arifin (2015), hotel merupakan bisnis jasa akomodasi yang didalamnya terdapat

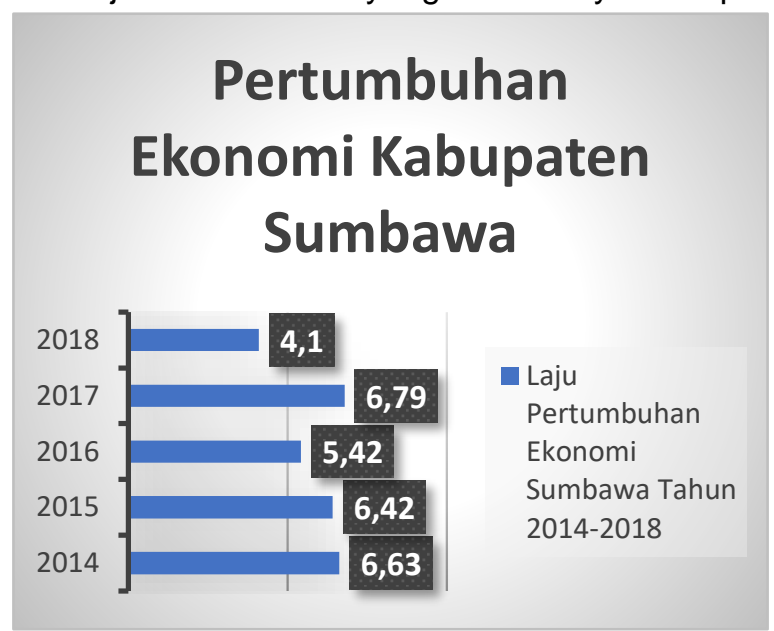

unsur pelayanan, kenyamanan, serta fasilitas penginapan yang dibutuhkan bagi mereka yang menghendaki sarana penginapan untuk kepentingan keluarga maupun liburan. Apartemen menurut Pramono (2016), kamar atau beberapa kamar (ruangan) yang diperuntukkan sebagai tempat tinggal, terdapat di dalam suatu bangunan yang biasanya mempunyai kamar atau ruangan-ruangan lain semacam itu. Menurut Afwan (2017), Asrama merupakan suatu tempat penginapan yang ditujukan untuk anggota suatu kelompok, umumnya murid-murid sekolah. Darsono (2017), mengatakan bahwasanya kontrakan adalah sebagai hunian yang biasanya menjadi objek perjanjian sewa-menyewa.

Menurut Buana (2011), menjamurnya kontrakan di suatu daerah memiliki latar belakang kebutuhan dari banyak golongan. Salah satunya adalah mahasiswa, pekerja, bahkan orang yang hanya ingin singgah sementara disuatu daerah tersebut. Tujuannya untuk menampung sementara, dimana penyediaan sarana ini bukan hal yang baru karena jasa ini sudah lama hadir dan hampir setiap masyarakat dari luar kota atau luar pulau menggunakannya kost atau kontrakan sekarang muncul di mana-mana. Hampir di setiap lokasi yang berdekatan dengan pabrik, kampus, sekolahan, perkantoran, atau pusat pertokoan banyak bermunculan rumah-rumah kost. Berbagai macam jenis dan bentuk rumah yang ditawarkan oleh pebisnis salah satu sarana yang dipersiapkan dalam rangka menunjang pendidikan tersebut adalah adanya sarana rumah 
sewa atau rumah kos untuk menampung sementara selama menempuh pendidikan terutama mahasiswa dari luar daerah dimana penyediaan sarana ini bukan hal yang baru karena jasa ini sudah lama hadir dan hampir setiap mahasiswa dari luar kota atau luar pulau menggunakannya. Berbagai macam jenis dan bentuk rumah yang ditawarkan oleh pebisnis rumah kos dengan ditunjang fasilitas yang ada membuat mahasiswa menjadi bingung untuk memilih jenis rumah kos yang sesuai dengan keinginan mahasiswa tersebut.

Menurut Masri (2018), menjelaskan bahwasanya kehadiran rumah kos mampu menjadi bagian dari pertumbuhan secara sosial ekonomi suatu daerah, sehingga kehadirannya dirancang untuk memenuhi kebutuhan hunian yang bersifat sementara dengan sasaran pasar umumnya adalah mahasiswa dan pelajar yang berasal dari luar kota maupun luar daerah namun tidak sedikit pula kos-kosan dihuni oleh masyarakat umum yang tidak memiliki tempat tinggal. Dimana berkeingan untuk berdekatan dengan lokasi aktifitas kampus dalam keseharian.

Universitas Teknologi Sumbawa (UTS) adalah lembaga pendidikan yang menampung banyak mahasiswa dari Pulau Sumbawa bahkan mahasiswa banyak yang berasal dari luar Pulau Sumbawa (Nusantara). Pada tahun pertama mahasiswa (Nusantara) masih diberikan fasilitas asrama untuk dijadikan tempat tinggal sementara untuk menyesuaikan kondisi daerah, akan tetapi setelah satu tahun berjalan mahasiswa (Nusantara) diminta untuk mencari tempat tinggal sendiri. Mahasiswa (Nusantara) juga mempunyai gaya hidup yang berbeda-beda karena masing-masing memiliki latar belakang yang berbeda juga.

\section{MAHASISWA UTS NUSANTARA 2016}

- TOTAL MAHASISWA NUSANTARA (256)

- MAHASISWA DI WILAYAH KAMPUS (218)

MAHASISWA DI WILAYAH PERKOTAAN (38)

Sumber: $\quad$ Administrasi PMB Universitas Teknologi Sumbawa 2019

Fenomena dari penelitian ini yang sudah peneliti jabarkan diawal, menjadikan peneliti perlu untuk mengetahui apa saja faktor yang mempengaruhi keputusan mahasiswa UTS (Nusantara) mengontrak rumah tinggal di wilayah perkotaan Sumbawa Besar. Maka berdasarkan latar belakang diatas, peneliti tertarik untuk meneliti lebih lanjut tentang keputusan mahasiswa untuk memilih tempat tinggal di daerah kota Sumbawa Besar dengan judul "(FaktorFaktor Yang Mempengaruhi Keputusan Mahasiswa Untuk Mengontrak Tempat Tinggal)". Peneliti tertarik mengangkat judul ini karena banyaknya mahasiswa yang memilih mengontrak di wilayah perkotaan Sumbawa Besar walau sangat jauh perbandingan apabila menginginkan menetap di Wilayah Kampus Universitas Teknologi Sumbawa ataupun Asrama Mahasiswa Nusantara yang ada di dalam lingkungan kampus.

\section{RUMUSAN MASALAH}

1. Faktor - faktor apa saja yang mempengaruhi keputusan mahasiswa Universitas Teknologi Sumbawa (Nusantara) angkatan 2016 dalam memilih tempat tinggal di wilayah perkotaan Sumbawa Besar

\section{HASIL DAN PEMBAHASAN}

Pada bab ini, peneliti akan mengemukakan hasil penelitian yang dilakukan selama mewawancarai pihak Mahasiswa Nusantara Universitas Teknologi Sumbawa angkatan 2016 dalam keputusan memilih tempat tinggal di wilayah perkotaan Sumbawa Besar. Setelah melakukan wawancara, peneliti mereduksi pembahasan tentang keputusan pemilihan dalam faktor keputusan dan bauran pemasaran jasa, maka peneliti melakukan wawancara kepada beberapa narasumber dari Mahasiswa Nusantara Universitas Teknologi Sumbawa angkatan 2016. Berikut ini merupakan table daftar narasumber atau informan dalam penelitian ini.

\begin{tabular}{|c|l|l|l|}
\hline $\begin{array}{c}\text { No } \\
\cdot\end{array}$ & \multicolumn{1}{|c|}{ Nama } & \multicolumn{1}{|c|}{ Alamat } & $\begin{array}{c}\text { Waktu } \\
\text { Wawancar } \\
\text { a }\end{array}$ \\
\hline 1 & $\begin{array}{l}\text { Muhammad } \\
\text { Aldi }\end{array}$ & $\begin{array}{l}\text { Jl. Baru, } \\
\text { Sumbawa } \\
\text { Besar }\end{array}$ & $\begin{array}{l}30 \\
\text { November } \\
201913.00 \\
-15.00 \\
\text { WITA. }\end{array}$ \\
\hline
\end{tabular}




\begin{tabular}{|c|c|c|c|}
\hline 2 & $\begin{array}{l}\text { Muhammad } \\
\text { Nur Sholeh }\end{array}$ & $\begin{array}{l}\text { Jl. Baru, } \\
\text { Sumbawa } \\
\text { Besar }\end{array}$ & $\begin{array}{l}30 \\
\text { November } \\
201919.00 \\
-\quad 21.00 \\
\text { WITA. }\end{array}$ \\
\hline 3 & $\begin{array}{l}\text { Hammid } \\
\text { Muammar }\end{array}$ & $\begin{array}{l}\text { Jl. Asdek } \\
\text { Samping } \\
\text { Muhsallah } \\
\text { Sumbawa } \\
\text { Besar. }\end{array}$ & $\begin{array}{ll}1 & \\
\text { desember } \\
201908.00 \\
-\quad 10.00 \\
\text { WITA. }\end{array}$ \\
\hline 4 & $\begin{array}{l}\text { Muhammad } \\
\text { Sahrul }\end{array}$ & $\begin{array}{l}\text { Jl. Baru, } \\
\text { Sumbawa } \\
\text { Besar }\end{array}$ & $\begin{array}{ll}01 & \\
\text { desember } \\
2019 & 15.00 \\
-\quad 17.00 \\
\text { WITA. }\end{array}$ \\
\hline 5 & $\begin{array}{l}\text { Muhammad } \\
\text { Itsar } \\
\text { Azzubair }\end{array}$ & $\begin{array}{l}\text { BTN, } \\
\text { Sumbawa } \\
\text { Besar. }\end{array}$ & $\begin{array}{ll}02 & \\
\text { desember } \\
201910.00 \\
-\quad 12.00 \\
\text { WITA. }\end{array}$ \\
\hline 6 & $\begin{array}{l}\text { Nauval } \\
\text { Abdurrahma } \\
\mathrm{n}\end{array}$ & $\begin{array}{l}\text { Jl. Asdek } \\
\text { Samping } \\
\text { Muhsallah } \\
\text { Sumbawa } \\
\text { Besar. }\end{array}$ & $\begin{array}{l}02 \\
\text { Desember } \\
201919.00 \\
\text { s.d } 21.00 \\
\text { WITA. }\end{array}$ \\
\hline
\end{tabular}

Sumber : Informan Penelitian

Faktor buaya didalam penelitian ini lebih menilai budaya sangat berkaitan dengan bahasa atau cara berkomunikasi, kebiasaan di suatu daerah atau adat istiadat, ada juga yang mengatakan bahwa arti budaya adalah suatu pola hidup yang tumbuh dan berkembang pada sekelompok manusia yang mengatur agar setiap individu mengerti apa yang harus dilakukan, dan untuk mengatur tingkah laku manusia dalam berinteraksi dengan manusia lainnya, hasil kutipan dari wawancara sebagai berikut:

"Untuk saat ini aman si, kita sama tetangga juga sering teguran, ya kalo budaya di daerah saya sekarang mah biasa aja, banyak jadi tak terlihat, masalah terpegaruh bisa jadi, karna kegiatan kita kan pasti menjadi luas, kenalan kita juga makin banyak, pinter - pinter aja kita gimana menyesuaikan budaya baru yang ada di lingkungan kita.". (Nauval, 2019)

"ya gimana ya, kita kan orang Bekasi, disana juga budaya mah budaya nyablak, kita mah kan orang
Betawi nih, jadi ya biasa aja gitu sama soal budaya mah". (Itsar, 2019)

Penjelasan dari setiap informan menjawab bahwasanya faktor budaya tidak mempengaruhi pilihan mereka untuk memilih tempat tinggal di wilayah perkotaan, dan dari keseluruhan informan hanya memberikan penjelasan bahwasanya di dalam hal faktor budaya adalah sebuah tambahan pembelajaran untuk mendapatkan pengalaman baru yang akan mereka pelajari dan di dapatkan selama menjadi seorang mahasiswa di tanah rantau.

Menarik untuk kita bahas lebih soal ketidak raguan mahasiswa Nusartara Universitas Teknologi Sumbawa angkatan 2016, kita bisa melihat ini menjadi sebuah tolak ukur mahasiswa Nusantara Universitas Teknologi Sumbawa angkatan 2016 tidak membeda - bedakan hal yang berbau dengan budaya, meraka bisa melebur dan memberikan yang terbaik terutama untuk citra kampus yang bisa melahirkan perajurit - perajurit hebat yang dididik di kampus Universitas Teknologi Sumbawa, dan yang memperkenalkan kampus dari setiap kalangan bahkan secara luas.

Informan 1, 2, 3, 4, 5, dan 6 tidak memiliki jawaban yang terlihat signifikan berbeda untuk berargumen dari topik budaya, sebuah kelebihan yang tidak dimiliki banyak orang, peneliti juga bisa mengatakan ini hal yang wajar terjadi di kampus yang mana menampung hampir seluruh mahasiswa dari setiap pulau yang berada di Indonesia, yang biasa disebutkan sebagai kampus mini Indonesia.

Budaya yang ada di wilayah kampus Universitas Teknologi Sumbawa sangatlah beraneka ragam, dan juga mahasiswa dari setiap daerah berinisiatif membuat sebuah paguyuban untuk wadah dari setiap daerah dengan maksud memperkenalkan budaya - budaya dari daerah mereka masing masing.

Faktor sosial didalam penelitian ini lebih melihat hubungan antar lembaga, individu dengan lembaga yang bersifat umum yang mendasar bagi masyarakat sekitar di lingkungan tempat tinggal, hasil kutipan dari wawancara sebagai berikut:

"Nah untuk keadaan sosial di wilayah tempat tinggal saya sebenernya aman - aman aja, tapi kendalanya cuma jarang ketemu aja, karna mayoritas tetangga di sekitar adalah pekerja". (Aldi, 2019)

"Sosial di lingkungan sini mah baik, tetangganya saling tegur sapa, saling ngasih bingkisan makanan gitu make mangkok, hidup deh lingkungan ini". (Muhammad Nur Sholeh, 2019)

Penjelasan dari semua informan menjawab bahwasanya faktor sosial tidak mempengaruhi 
pilihan mereka untuk memilih tempat tinggal di wilayah perkotaan, dari keseluruhan informan hanya memberikan penjelasan bahwasanya pilhan mereka di dalam hal faktor sosial adalah amannya sosial yang ada di lingkungan mereka, walaupun adanya masalah - masalah yang ada di lingkungan wilayah perkotaan, mahasiswa Nusantara angkatan 2016 tidak terpengaruhi dengan hal - hal yang negatif.

Peneliti juga ingin menjelaskan bahwasanya mahasiswa Nusantrara Universitas Teknologi Sumbawa telah di berikan pengajaran tentang bersosialisasi di kalangan masyarakat, berawal dari di berikannya fasilitas asrama untuk penunjang 1 tahun pertama di tanah rantau, disitulah mereka belajar bagaimana sangat dibutuhkannya sosial yang baik antar sesama, tolong - menolong adalah cara bersosial yang sangat kita sering temui, ditambah lagi dengan kegiatan kampus yaitu kuliah kerja nyata (KKN) yang disana mahasiswa Nusantara angkatan 2016 bisa lebih mengenal kehidupan sosial dengan berkelompok disuatu daerah.

Psikologi dapat diartikan pula dengan ilmu yang mempelajari tentang segala hal yang berhubungan dengan jiwa, hakekatnya, asal usulnya, proses bekerjanya dan akibat-akibat yang ditimbulkannya, dan di penelitian ini sisi psikologis di bagi untuk beberapa kategori yaitu motivasi, persepsi, dan tahapan - tahapan pengambilan keputusan.

Dari wawancara yang telah dilakukan oleh peneliti faktor psikologis dalam keputusan pemilihan tempat tinggal untuk seorang mahasiswa penjelasan dari point motivasi seperti penjelasan faktor budaya dan faktor sosial, untuk poin psikologis tidak terlihat jawaban yang signifikan yang peneliti dapatkan, hampir mengarah kepada keinginan mereka ingin sekali memiliki tempat tinggal yang nyaman dan dikelilingi akes yang mudah untuk memenuhi kebutuhan sehari - hari seorang mahasiswa.

Dari akses untuk memenuhi kebutuhan sehari - hari sampai dengan keinginan mereka dekat dengan tempat hiburan, disini tempat hiburan tidaklah memiliki nilai yang negatif, hanya menjadi tempat dimana mahasiswa bisa mengeluarkan keluh kesahnya selama dirinya ada di wilayah kampus yang memikirkan tentang akademik. Dengan adanya motivasi mahasiswa memiliki tempat tinggal yang nyaman di wilayah perkotaan bisa memancing pula motivasi untuk teman temannya memilih tempat tinggal di wilayah perkotaan, hasil kutipan dari wawancara sebagai berikut:

"Motivasi gue nambah mau di kota karna dari awal keinginan gue mau di kota dan ditambah kelompok acuan gue juga mau banget di kota, jadi ya tambah semangat lah memilih tempar tinggal di wialayh perkotaan, gak pernah mau ah tinggal di wilayah kampus, cukup satu tahun pertama pas jadi maba.". (Amar, 2019)

"Motivasi yang saya miliki cuma mengutamakan kenyamanan aja selama ini, dan gak ada yang lain". (Sahrul, 2019)

Produk adalah segala sesuatu yang dapat ditawarkan kepada pasar untuk memuaskan suatu keinginan atau kebutuhan konsumen. Produk dapat berupa sub kategori yang menjelaskan dua jenis seperti barang dan jasa yang ditujukan kepada target pasar. Produk dalam penelitian ini adalah segala sesuatu yang ditawarkan, dimiliki, digunakan atau dikonsumsi sehingga bisa memuaskan keinginan dan kebutuhan termasuk di dalamnya berupa fisik, tempat, orang, jasa, gagasan, serta organisasi, dan didalam penelitian ini produk lebih mengarah ke bentuk tempat tinggal yang disiapkan untuk di kontrak oleh mahasiswa nusantara Universitas Teknologi Sumbawa angkatan 2016, hasil kutipan dari wawancara sebagai berikut:

"Menurut saya rumah kontrakan di wilayah perkotaan itu lebih modern, dan diwilayah kampus juga kan masih pedesaan yang notabene rumah panggung, bedannya rumah kontrakan di wilayah perkotaan lebih baik lah gitu, jadi ya saya lebih baik di kota sih dari pada didaerah kampus yang emang kita udah pada tau giman bentuknya juga". (Itsar, 2019)

"Pasti itu, karena rumah di wilayah perkotaan lebih bagus dibandingkan dengan rumah yang ada disekitar kampus, dari bentuk rumah ya diliatnya, kita juga kan tau nih di wilayah kampus itu rumah kebanyakan belum di plester, jadi ya agak gimana ya, kurang aja gitu, mending di wilayah perkotaan kalo kita mau bandingkan". (Nauval, 2019)

Dari penjelasan peneliti memiliki kesimpulan yang peneliti dapatkan setelah melakukan wawancara terhadap seluruh informan mengenai faktor product/produk pada faktor - faktor yang mempengaruhi keputusan mahasiswa untuk mengontrak tempat tinggal adalah mahasiswa lebih memilih tempat tinggal yang masuk dalam kategori modern menurut informan, dan informan juga mengatakan bahwasanya tempat tinggal di wilayah perkotaan bisa menjadi pilihan yang tepat untuk mengontrak tempat tinggal, tidak lupa peneliti menanyakan bagaimana kondisi produk yang ada di wilayah kampus untuk mendapatkan sebuah pertimbangan, dan peneliti mendapatkan jawaban dari informan yang bisa dikatakan tempat tinggal di wilayah kampus tidak bisa di terima dalam hal produk yang bisa membuat tempat tinggal menjadi tempat yang nyaman untuk mereka beristirahat dan melakukan 
kegiatan - kegiatan yang merelaka lakukan sehari - hari.

Harga adalah sejumlah uang yang mempunyai nilai tukar untuk memperoleh keuntungan dari memiliki atau menggunakan suatu produk atau jasa. Harga merupakan bauran pemasaran yang bersifat fleksibel di mana suatu harga akan stabil dalam jangka waktu tertentu tetapi dalam seketika harga dapat meningkat atau menurun yang terdapat pada pendapatan dari hasil penjualan. Harga yang akan kita bahas dalam penelitian ini lebih mengarah kepada pembayaran jasa tempat tinggal dan harga adalah sejumlah uang yang dibebankan terhadap suatu produk (barang atau jasa), atau jumlah nilai yang harus dibayar konsumen demi mendapatkan manfaat dari produk tersebut, hasil kutipan dari wawancara sebagai berikut:

"Harga mah kita menyesuaikan ya, kalo temen temen kontrakan kita bisa dengan harga yang tinggi dan emang fasilitas yang baik ya kenapa kita gak pilih, tapi kalo emang temen temen yang barengan sama kita gak bisa dengan harga yang tinggi ya mau diapain kan". (Aldi, 2019)

"Untuk mempertimbangkan bias dibilang iya, karena saya sebelum mengontrak di wilayah perkotaan mencari dulu nih rata - rata harga rumah yang di sewa untuk mahasiswa, dan sebenarnya banyak juga rumah di wilayah kampus, tapi kebanyakan yang gak di pleseter, ketka ada yang di plester biasanya ada orangnya, kalo di kota dengan harga yang gak mahal banget atau standar gitu ya membuat kita nyaman aja". (Sholeh, 2019)

Kesimpulan yang peneliti dapatkan setelah melakukan wawancara terhadap seluruh informan mengenai faktor price/harga pada faktor - faktor yang mempengaruhi keputusan mahasiswa untuk mengontrak tempat tinggal adalah tidak terlihat berbeda untuk harga di wilayah kampus dan di wilayah perkotaan walaupun di daerah perkotaan lebih mahal di bandingkan dengan harga tempat tinggal di wilayah kampus, untuk keputusan memilih tempat tinggal di wilayah perkotaan karena lebih banyak kebutuhan mereka yang ada di wilayah perkotaan, seperti akses yang ada di wilayah perkotaan lebih baik di bandingkan di wilayah kampus, untuk keuangan dalam pilihan mengontrak di wilayah perkotaan mereka membicarakan terlebih dahulu terhadap teman teman yang ingin tinggal bersama dan menyesuaikan rumah setelah mendapatkan hasil keuangan dari kelompok informan masing masing.

Tempat memiliki peranan yang sangat penting dalam membantu perusahaan guna memastikan produknya. Tempat merupakan berbagai kegiatan yang dilakukan oleh perusahaan untuk membuat produknya mudah diperoleh dan tersedia pada konsumen sasaran. Hal ini dikarenakan tujuan dari tempat adalah menyediakan barang dan jasa yang dibutuhkan dan diinginkan oleh konsumen pada waktu dan tempat yang tepat, hasil kutipan dari wawancara sebagai berikut:

"Udah gak ada ya kayanya, habisnya udah nyaman di kota si untuk tempat tinggal mah, gak ada duanya lah, dan aktifitas juga enak di kota". (Amar, 2019)

"Di wilayah perkotaan banyak hiburan, lebih deket sama tempat kita membeli keperluan sehari hari, enak buat nongkrong bareng temen temen kalo di kampus kan sepi banget tuh jadi gak enak buat nongkrong". (Sahrul, 2019)

Kesimpulan yang peneliti dapatkan setelah melakukan wawancara terhadap seluruh informan mengenai faktor place/tempat pada faktor - faktor yang mempengaruhi keputusan mahasiswa untuk mengontrak tempat tinggal adalah sangat terlihat sama, dari informan yang menginginkan akses yang lebih baik dan mempertimbangakan akses yang ada di wilayah kampus yang jauh berbeda dari yang ada di wilayah perkotaan, dari akses internet murah seperti telkom, pasar untuk kebutuhan sehari hari, dan tempat hiburan yang bisa mereka dapatkan lebih mudah jika mereka memilih tempat tinggal di wilayah perkotaan.

Promosi adalah semua kegiatan yang dilakukan perusahaan untuk mengkomunikasikan dan mempromosikan produknya kepada pasar sasaran. Promosi dilakukan dengan menggunakan alat-alat promosi yang ada sebagai cara untuk memperkenalkan suatu produk atau jasa, hasil kutipan dari wawancara sebagai berikut:

"Kebanyakan mulut ke mulut si, kaya dari temen temen deket tapi kalo sekarang mah ada juga si yang lewat media sosial, kaya jual beli sumbawa di facebook, atau BC whatsapp gtu deh yang biasa kita dapetin di grup grup yang ada di kampus". (Itsar, 2019)

"Kalo promosi saya memasukan ke informasi kayanya, dari facebook si biasanya, atau dari mulut ke mulut aja, banyak juga kan temen kita yang dari warga asli sumbawa yang mempunyai kenalan - kenalan pemilik rumah yang bisa di gunakan rumahnya”. (Nauval, 2019)

Kesimpulan yang peneliti dapatkan setelah melakukan wawancara terhadap seluruh informan mengenai faktor promotion/promosi pada faktor - faktor yang mempengaruhi keputusan mahasiswa untuk mengontrak tempat tinggal adalah informan menjadikan promosi menjadi salah satu pertimbangan mereka untuk 
memilih tempat tinggal yang ada di wilayah perkotaan, dan dari setiap informan mendapatkan promosi mulut ke mulut, sebaran di grup whatsapp, dan juga grup jual beli wilayah yang ada di aplikasi media sosial yaitu facebook.

Proses seleksi, pelatihan, dan pemotivasian karyawan yang nantinya dapat digunakan sebagai pembedaan perusahaan dalam memenuhi kepuasan pelanggan, hasil kutipan dari wawancara sebagai berikut

"Ya kalo emang pemilik rumah atau penjaga rumahnya baik dan enak ke kita ya kita pilih, gak banyak si kalo gue mah". (Aldi, 2019)

"Gimana ya jelasinnya kalo ini kan kita pas mau masuk pasti harus kenal kan nih sama pemilik rumah, tapi kalo emang pemilik rumah gak bisa masuk ke kita ya kita juga gak mau si jadiin rumah itu, ceritannya nih ya kaya penjaga atau pemilik rumahnya galak atau bagaimana pun, ya kita juga mending nyari dulu dari pada memutuskan untuk tinggal disana”. (Sholeh, 2019)

Kesimpulan yang peneliti dapatkan setelah melakukan wawancara terhadap seluruh informan mengenai faktor people/orang pada faktor - faktor yang mempengaruhi keputusan mahasiswa untuk mengontrak tempat tinggal adalah informan menjadikan pemilik/penjaga tempat tinggal adalah seseorang yang dekat dengan informan, dan itu bisa membuat informan sendiri ingin untuk menetap di rumah kontrakan tersebut, karena jamuan atau cara berbicara yang bisa diseimbangakan dengan informan yang akan menetap.

Bukti yang dimiliki oleh penyedia jasa yang ditujukan kepada konsumen sebagai usulan nilai tambah konsumen. Bukti fisik merupakan wujud nyata yang ditawarkan kepada pelanggan ataupun calon pelanggan, hasil kutipan dari wawancara sebagai berikut:

"Bentuk fisik pasti nyari yang nyaman si dari pandangan kita masing - masing, ada kamar dan ada kamar mandi yang bagus gak terlalu sempit dan bersih, kalo bentuk fisik si yang luas si biar gak pengap, dan enak juga kalo mau jamu tamu temen temen kampus atau temen daerah asal yang lagi main ke Sumbawa”. (Amar. 2019)

"kalo saya sih gak terlalu ngeliat di fisik, maksudnya yang penting itu eh itu bentuk fisik deh hehe,melihat langsung si rumah nyaman mah, kaya halaman luas, kamar banyak, dan juga menurut anak anak itu udah pas ya ambil tapi kalo emang enggak pas bisa cari yang lain intinya mah diwilayah perkotaan". (Itsar, 2019)

Kesimpulan yang peneliti dapatkan setelah melakukan wawancara terhadap seluruh informan mengenai faktor physical evidence/bentuk fisik pada faktor - faktor yang mempengaruhi keputusan mahasiswa untuk mengontrak tempat tinggal adalah dari bentuk tempat tinggal yang akan di tinggali seperti dari jumlah kamar dan luas kamar, luas rumah, alas tempat tinggal yang menggunakan lantai, memiliki kamar mandi, dapur, halaman depan yang luas dan memilik pagar, dan lain sebagainya.

Semua prosedur aktual, mekanisme dan aliran aktivitas dengan mana jasa disampaikan yang merupakan sistem penyajian atas operasi jasa". Dalam penelitian ini, peneliti meneliti tentang komponen dalam struktur keputusan pembelian yaitu, harga sewa, fasilitas, lokasi, pendapatan orang tua, dan lingkungan. Semua yang akan di bahas adalah faktor yang dapat mempengaruhi sebuah keputusan mahasiswa dalam memilih rempat tinggal.

"Proses si kaya biasa ya, kita cari tahu dulu nih rumah mana yang di kontrakin, terus kita tentuin tuh rumah mana yang bakalan kita pilih, kita sortir dari harga, fasilitas, akses dan lain lainnya, ketika emang udah nemu rumah yang cocok ya kita langsung membuat janji dengan pemilik rumah bagaimana kelanjutannya, nah pas ketemu dengan pemilik rumah atau penjaga rumah ya kita membuat kesepakan kapan masuk dan bagaimana pembayarannya, nah masalah pembayaran itu yang paling penting karna sangat sensitif si ya ngomongin duit mah, kita butuh banget, dan yang pemilik tempat tinggalnya juga kan butuh juga, makanya ini yang biasanya kita bahas Panjang dengan pemilik rumah, ketika masalah pembayaran telah selesai baru deh kita menentukan kapan mulai bisa mengisi rumahnya". (Aldi, 2019)

"Jauh dari hari kita dapet rumah kontrakan yang sekarang itu dengan perjalanan dan drama yang Panjang, kita nyari nyari rumah keliling wilayah perkotaan berhari hari sampe kita dapet nih rumah dan terlihat masuk dalam ketegori kita lah, kan depan rumahnya tuh ada nomor hape yang bisa dihubungi, nah kita hubungi dan membuat janji untuk bertemu dalam niat untuk survei rumah yang kita inginkan, setelah dapet nih hari dan jam yang pas kita langsung deh tuh mengira ngira harga dll, nah pas dihari dimana kita didalam perjanjian kita survei langsung dan pas banget harga masuk juga ke kantong kita, gak gede amat gak murahan juga, terus kita kumpul sama anak anak yang mau ngontrak bareng dan menetukan kembali kepada sang penjaga rumah untuk menginformasikan kita jadi untuk mengambil rumah itu, setelah pembayaran yang sudah kita bahas sebelumnya ya jadi semua berjalan secara lancar, gak ribet si kalo gitu mah masih masuk kategoti lancar, Alhamdulillah.". (Sahrul, 2019)

Kesimpulan yang peneliti dapatkan setelah melakukan wawancara terhadap seluruh 
informan mengenai faktor proses pada faktor faktor yang mempengaruhi keputusan mahasiswa untuk mengontrak tempat tinggal adalah kemudahan untuk mendapatkan tempat tinggal yang nyaman dan tidak lupa kebutuhan dari informan dan dari setiap individunya masing masing, informan yang saya teliti keseluruhan menjawab menginginkan proses yang mudah dari awal pencarian hingga memutuskan tempat tinggal mana yang akan di kontrak oleh informan dan kelompoknya, dari alur jawaban wawancara yang di lakukan oleh peneliti semua memilik kesamaan, dari pencarian rumah sebanyak banyaknya dan memilah dari seluruh kebutuhan dan kemampuaan informan, setelah itu membuat janji dengan pemilik/penjaga tempat tinggal untuk membicarakan bagaimana cara untuk mengambil alih hak tinggal di rumah yang telah di tentukan informan dan kelompoknya.

\section{KESIMPULAN}

Telah dilakukan analisis mengenai faktor - faktor yang mempengaruhi keputusan mahasiswa Nusantara Universitas Teknologi Sumbawa angkatan 2016 mengenai keputusan memilih tempat tinggal. Adapun kesimpulan dari penelitian ini yaitu:

1. Dalam keputusan Mahasiswa Nusantara Universitas Teknologi Sumbawa angkatan 2016 dalam memilih tempat tinggal di wilayah perkotaan adalah dengan pertimbangan yang cukup matang, tidak hanya karena gengsi yang mereka miliki, akan tetapi dengan melihat produk tempat tinggal di wilayah perkotaan itu sendiri, melihat rata - rata harga tempat tinggal di wilayah perkotaan, melihat juga akses yang ada di wilayah perkotaan lebih lengkap.

2. Mahasiswa Nusantara Universitas Teknologi Sumbawa angkatan 2016 memiliki toleransi yang tinggi terhadap perbedaan, dengan bertahan di tanah rantau yang jauh dari kampung halamannya masih bisa bergerak bebas walau kadang saja bisa memiliki sebuah masalah, akan tetapi mahasiswa Nusantara Univesitas Teknologi Sumbawa angkatan 2016 terbukti bisa membuktikan kedewasaannya dalam menyikapi persoalan kehidupan yang ada.

3. Mahasiswa Nusantara Universitas Teknologi Sumbawa angaktan 2016 menjadi mayoritas memilih tempat tinggal di wilayah perkotaan karena banyak hal, dari poin bauran pemasaran 7P yang jawabanya tidak terlihat signifikan berbeda.

4. Mahasiswa Nusantara Universitas Teknologi Sumbawa khususnya angkatan 2016 telah menggambarkan bahwasanya faktor budaya yang ada di tanah rantau menjadi media pembelajaran baru tanpa merubah budaya mereka yang biasa mereka lakukan di kampung halaman dan menjadi nilai tambah untuk masing - masing individu, seperti pribahasa Bineka Tunggal Ika yang memiliki arti berbeda - beda tetapi tetap satu

5. Mahasiswa Nusantara Universitas Teknologi Sumbawa khususnya angkatan 2016 telah memberikan dampak sosial yang baik bagi masayarakat sekitar tempat tinggal mereka, dan juga itu menjadi nilai tambah bagi kampus Universitas Teknologi Sumbawa yang telah berhasil membentuk karakter mahasiswanya menjadi calon pemimpin masa depan.

6. Mahasiswa Nusantara Universitas Teknologi Sumbawa khususnya angkatan 2016 mempunyai motivasi untuk tinggal di wilayah perkotaan Sumbawa Besar adalah karena adanya akses dan fasilitas untuk menunjang kehidupan di tanah rantau, seperti akses pasar yang lebih mudah, akses kesehatan lebih terjangkau, dan fasilitas seperti penunjang belajar yaitu internet yang tersedia di wilayah perkotaan adalah Telkom, yang kadang juga Telkom menjadi rumah bagi mahasiswa untuk mengerjakan tugas - tugas yang diberikan oleh dosen untuk mahasiswanya di kampus.

\section{SARAN}

1. Pengusaha properti di wilayah kampus dan di wilayah perkotaan Untuk pengusaha properti di lingkungan kampus jika menginginkan tempatnya usahanya ingin di idam - idamkan oleh mahasiswa Nusantara Universitas Teknologi Sumbawa harus memberikan fasilitas, bentuk fisik yang lebih modern, akses untuk kebutuhan sehari hari dengan bekerja sama dengan kampus ataupun pemerintah, dan juga untuk pengusaha properti di wilayah perkotaan Sumbawa Besar harus lebih matang mempersiapkan kebutuhan dengan permintaan yang besar dari mahasiswa Universitas Teknologi Sumbawa yang sekarang terlihat membutuhkan tempat tinggal di wilayah perkotaan Sumbawa Besar karena telah terpenuhi kebutuhan mahasiswa di sekitar lingkungan wilayah perkotaan Sumbawa Besar.

2. peneliti yang mempunyai pembahasan yang sama harus lebih mematangkan persiapan disesi wawancara, agar tidak membuat kerja yang lebih di waktu wawancara informan, dengan persiapan yang lebih matang peneliti sekarang mempunyai pandangan akan lebih mudah dalam sesi wawancara yang akan datang.

3. kampus tercinta Universitas Teknologi Sumbawa peneliti berharap kampus bisa memberikan fasilitas kepada mahasiswa Nusantara atau mahasiswa rantau dengan 
fasilitas pencatatan tempat tinggal mahasiswa agar mahasiswa yang berada tidak di lingkungan kampus masih merasa mendapatkan pengamanan lebih.

4. mahasiswa Universitas Teknologi Sumbawa yang masih menduduki kursi mahasiswa, peneliti menyarankan untuk memilih tempat tinggal yang nyaman sesuai kemampuan ekonomi dari masing - masing individu, kenyamanan, dan akses yang dibutuhkan setingkat mahasiswa, sepeti jaringan internet, rumah sakit, pasar, dan lain - lain.

\section{DAFTAR PUSTAKA}

Adhaghassani. 2016. Strategi Bauran Pemasaran (Marketing Mix) 7p (Product, Price, Place, Promotion, People, Process, Physical Evidence). Skripsi. Yogyakarta: Universitas Negeri Yogyakarta.

Afwan.2017. Perbandingan Hasil Belajar Antara Siswa Yang Tinggal Di Asrama Dengan Siswa Yang Tinggal Di Rumah Orang Tua.Skripsi. Lampung: Universitas Lampung.

Amaria.2011. Faktor Yang Mempengaruhi Keputusan Membeli Dan Brand Image Produk Minute Maid Pulpy Orange.skripsi. Semarang: Universitas Negri Semarang.

Arifin.2015. Pengaruh Kualitas Pelayanan Terhadap Kepuasan Konsumen Di Hotel Kara Guest House Sragen. Skripsi. Surakarta: Universitas Muhammadiyah Surakarta.

Badri.2012. Analisis Faktor Yang Menjadi Pertimbangan Mahasiswa Dalam Memilih Tempat Kost Di Kawasan Kampus UNEJ. Jember: Universitas Jember.

Dewiytanti.2017. Pengaruh Suasana Toko (Cafe) terhadap Keputusan Pembelian pada Dongeng Kopi Jogja. Skripsi. Sleman: Universitas Gajah Mada.

Dietrich.2010. Decision Making: Factors that influence Decision Making, Heuristics Used, and Decision Outcomes. Inquiries Journal/Student Pulse. 2(2), 1-8.

Riyanto. 2018. Pengaruh Citra Merek Kepercayaan Merek Dan Kepuasan Pelanggan terhadap Loyalitas Merek. Skripsi. Purwokerto: Universitas Muhammadfiyah Purwokerto.
Rahmatullah.2016. pengaruh kualitas Produk Dan Harga Terhadap Keputusan Pembelian Sepeda Motor Honda Spacy Pada Pd. Mawar Putra Motor Sumedang. Sripsi. Bandung: Universitas Pasundan.

Gumilang.2016. Metode Penelitian Kualitatif Dalam Bidang Bimbingan Dan Konseling.2(2):144-159.

Nilakusmawati.2012. Faktor-Faktor Yang Memengaruhi Keputusan Mahasiswa Dalam Memilih Rumah Kost. eJurnal Matematika. 1(1), 25-31.

Rachmawati.2007. Pengumpulan Data Dalam Penelitian Kualitatif.11(1):25-40.

Jihan. 2017. Problematika Perjanjian Sewewenyewa Rumah Kos Dengan Perjanjian Lisan.Skripsi. Surakarta: Universitas Muhammadiyah Surakarta.

Rasyid. 2018. Analisis Dampak Sosial Kemajuan Pembangunan Rumah Kos Sekitar Kampus Uin Alauddin Makassar Di Kelurahanromang Polong Kecamatan Somba Opu Kabupaten Gowa. 15:3.

Muhajir. Metode Penelitian Kualiitatif. (Yogyakarta: Rake Sarasia, 1996), 31.

Dara.2016. Identifikasi Potensi Desa Vokasi Bidang Arsitektur Desa Sudalarang Kabupaten Garut Jawa Barat.skipsi. Bandung:Universitas Pendidikan Indonesia.

Diah.2009.Analisi Kepuasan Konsumen Dan Bauran Pemasaran. Skripsi. Yogyakarta: Universitas Sanata Dharma Yogyakarta.

Pramono. 2016. Kajian Obyek Secara Umum Tentang Apartemen.2:11.

Ramdani, Azhari.2016. Tinjauan Yuridis Penguasaan Tanah Pertanian bagi Petani Menurut Undang-Undang No.56 Tahun 1960 dan Undang-Undang No. 19 Tahun 2013. Skripsi, Sleman: Universitas Gajah Mada.

Rosadi, D. Andriawan, FO. 2016.Aplikasi Sistem Informasi Pencarian Tempat Kos Dikota Bandung Berbasis Android Jurnal Computech \& Bisnis. 10:50.

Putri.2016. Pengaruh Kualitas Produk Dan Harga Terhadap kepuasan Konsumen Dan Dampaknya Terhadap kepercayaan 
JURNAL MANAJEMEN DAN BISNIS VOL.2.NO.2 2019

http://jurnal.uts.ac.id

konsumen The Botol Sosro.

Skripsi.Bandung: Universitas Pasundan.

Darsono. 2017. Latar Belakang Merabahnya Kontrakan. 13:1.

Sugiyono, Metode Penelitian Kuantitatif Kualitatif dan $R \& D$, (Bandung: Alfabeta, 2008), 300.

Sugiyono, Metode Penelitian Kuantitatif Kualitatif dan $R \& D$, (Bandung: Alfabeta, 2008), 301.

Surya, Fizza.2019. Statistik Daerah Kabupaten Sumbawa. Sumbawa: Badan Pusat Statistik Kabupaten Sumbawa.

Suryadi, K., \& Ramdhani, M. A.1998. Sistem Pendukung Keputusan Suatu Wacana Struktural Idealisasi Dan Implementasi Konsep Pengambilan Keputusan. Bandung: PT Remaja Rosdakarya. 